\title{
Recalcitrant Compounds Removal in Raw Leachate and Synthetic Effluents Using the White-Rot Fungus Bjerkandera adusta
}

\author{
Alessandra Bardi ${ }^{1, *}$, Qiuyan Yuan ${ }^{2}$ (D) , Valeria Tigini $^{3}$, Federica Spina ${ }^{3}$ (D), \\ Giovanna Cristina Varese ${ }^{3}$, Francesco Spennati ${ }^{4}$ (i), Simone Becarelli ${ }^{1,5}$, Simona Di Gregorio ${ }^{1}$, \\ Giulio Petroni ${ }^{1}$ and Giulio Munz ${ }^{4}$ \\ 1 Department of Biology, University of Pisa, Via Luca Ghini 13, 56126 Pisa, Italy; \\ simone.becarelli@biologia.unipi.it (S.B.); simona.digregorio@unipi.it (S.D.G.); giulio.petroni@unipi.it (G.P.) \\ 2 Department of Civil Engineering, University of Manitoba, 15 Gillson Street, R3T 5V6, \\ Winnipeg, MB R3T 2N2, Canada; qiuyan.yuan@umanitoba.ca \\ 3 Department of Life Sciences and Systems Biology, University of Turin, viale Mattioli 25, 10125 Torino, Italy; \\ valeria.tigini@unito.it (V.T.); federica.spina@unito.it (F.S.); cristina.varese@unito.it (G.C.V.) \\ 4 Department of Civil and Environmental Engineering, University of Florence, Via S. Marta 3, \\ 50139 Florence, Italy; francesco.spennati@unifi.it (F.S.); giulio@dicea.unifi.it (G.M.) \\ 5 BD Biodigressioni S.r.l., Lungarno Mediceo, 56127 Pisa, Italy \\ * Correspondence: alessandra.bardi@for.unipi.it; Tel.: +39-050-221-1356
}

Received: 6 September 2017; Accepted: 24 October 2017; Published: 27 October 2017

\begin{abstract}
Recalcitrant compounds limit the efficiency of conventional biological processes for wastewater treatment, representing one of the major issues in the field. This study focused on the treatment of three effluents with White-Rot-Fungus (WRF) Bjerkandera adusta MUT 2295 in batch tests, with biomass cultivated in attached form on polyurethane foam cubes (PUFs) to test its efficiency in the removal of the target effluents' recalcitrant fraction. Treatment efficiency of $B$. adusta was evaluated on landfill leachate (Canada) and two solutions containing synthetic recalcitrant compounds, which were prepared with tannic and humic acid. Chemical Oxygen Demand (COD) and color removal, the production of manganese peroxidases, and the consumption of a co-substrate (glucose) were monitored during the experiment. Biological Oxygen Demand $\left(\mathrm{BOD}_{5}\right)$ and fungal dry weight were measured at the beginning and at the end of the experiment. After co-substrate addition, effluent COD was $2300 \pm 85,2545 \pm 84$, and $2580 \pm 95(\mathrm{mg} / \mathrm{L})$ in raw leachate and tannic and humic acids, respectively. COD removal of $48 \%, 61 \%$, and $48 \%$ was obtained in raw leachate and in the synthetic effluents containing tannic and humic acids, respectively. Color removal of $49 \%$, $25 \%$, and $42 \%$ was detected in raw leachate and in tannic and humic acid solutions, respectively. COD and color removals were associated with the increase of fungal dry weight, which was observed in all the trials. These results encourage the use of the selected fungal strain to remove tannic acid, while further investigations are required to optimize leachate and humic acid bioremediation.
\end{abstract}

Keywords: bioremediation; landfill leachate; recalcitrant compounds; wastewater treatment; white-rot fungi

\section{Introduction}

The concept of recalcitrant compounds was introduced to define structurally novel and naturally occurring compounds resistant to microbial degradation and persistent in the environment for extended periods [1]. The presence of these compounds has emerged as a major issue in wastewater treatment processes since the state-of-the-art technologies for their removal are, in general, complex 
and costly [2]. The search for efficient and sustainable technologies has led to an increasing interest in advanced biological processes.

In particular, White-Rot Fungi (WRF) and their extracellular enzymes have been investigated for the removal of hazardous and recalcitrant pollutants [3]. The efficiency of WRF in degrading recalcitrant molecules is related to their ability to secrete extracellular enzymes such as lignin peroxidases $(\mathrm{LiP})$, manganese peroxidases $(\mathrm{MnP})$, or laccases, which are involved in lignin and lignocellulosic substrate degradation [4]. Compared to the use of bacteria, treatments involving fungi could be advantageous as they offer an easier degradation of high molecular mass organic pollutants and a higher rate of COD reduction in several industrial wastewaters [4]. Thus, WRF's potential to depolymerize several compounds, traditionally recalcitrant in conventional wastewater treatment processes, could be exploited as a preliminary step to allow subsequent bacterial degradation [5]. Up to date, the use of WRF has been effective at laboratory level toward several xenobiotic, including phenols, dyes, hydrocarbons, textile effluents, pharmaceuticals, waste products of pulp and paper mill industries, pesticides, and insecticides [6].

This fungal-based approach showed promising results also on landfill leachate, highly polluted wastewater, whose decontamination requires innovative and sustainable technologies [2]. Despite the high variability found in landfill leachate chemical composition, a common basal composition can be observed in the majority of landfill leachates [7]. In particular, according to Ghosh et al. [7], four main categories of pollutants can be grouped: (i) dissolved organic matter, including volatile fatty acids and more refractory compounds such as fulvic-like and humic-like compounds; (ii) inorganic macro components; (iii) heavy metals; and (iv) xenobiotic organic compounds such as aromatic hydrocarbons, phenols, and chlorinated aliphatics. Toxic effects of leachate have been reported on microbes, algae, invertebrates, plants, and mammals, indicating the environmental risk posed by landfill leachates to the ecosystem as a whole, including humans [8].

At the moment, only a few studies are available in literature about the use of WRF in landfill leachate treatment and the majority of them have been performed through batch tests. Ellouze et al. [4,9] detected COD removal efficiencies of $68 \%$, $79 \%$, and $90 \%$ for Phanerochaete chrysosporium, Trametes trogii, and Lentinus tigrinus, respectively, with 50\% diluted leachate (initial COD: $8000 \mathrm{mg} / \mathrm{L}$ ) accompanied by significant enzyme secretion and a high reduction in the toxicity expressed as percentage of Vibrio fischeri bioluminescence inhibition (\%BI $<20 \%)$. Kalčikova et al. [3] reported a maximum COD removal of $60 \%$ using extracellular enzymes obtained from Dichomitus squalens on $50 \% v / v$ landfill leachate. Tigini et al. [10] provided evidence of the efficiency of autochthonous and allochthonous fungal strains in landfill leachate treatment, showing their ability to significantly reduce its toxicity. The same authors indicated $40 \%$ of color removal from landfill leachate, using Lopharia spadicea MUT 1585. Awasthi et al. [11] reported high biosorption rates for cadmium by inoculating the enzyme produced by Trichoderma harzianum in solid waste leachate. Furthermore, Ghosh and Thakur [12] reported considerable contaminant-level reductions on landfill leachate, achieved with Phanaerochaete sp. ISTL01, through biosorption. Among the studies related to WRF in the bioremediation of landfill leachate, only a small percentage have been performed in continuous systems. Indeed, Saetang and Babel [13] reported 63\% color removal, 52\% reduction of 5-day-Biological Oxygen Demand $\left(\mathrm{BOD}_{5}\right)$, and $42 \%$ COD removals in continuous experiments with optimum conditions. Ghosh et al. [14] proposed a combined approach of fungal and bacterial treatment, using bioreactors. The combined treatment led to $76.9 \%$ of COD removal and $45.4 \%$ of decolorisation, under optimized conditions. Furthermore, Bardi et al. reported a maximum COD removal of $63 \%$ using WRF on old landfill leachate, which is characterized by low $\mathrm{BOD}_{5} / \mathrm{COD}(<0.1)$ and high concentrations of high refractory humic and fulvic acids. These authors performed experiments on landfill leachate using bioreactors, in which two co-substrate dosages were applied: at the beginning of the test and when the performance, in terms of COD removal, was decreasing [15].

The potential of WRF has also been investigated on humic acids, which are very complex and recalcitrant compounds, naturally occurring in landfill leachate. Thanks to their high adsorbing 
abilities, humic acids can bind with other substances, leading to serious co-contamination problems. As a consequence, the presence of humic acids can negatively affect also the quality of public water supplies [16]. Batch tests performed on the removal of these compounds using Bjearkandera adusta showed a full decolorisation of $0.03 \%$ humic acids from brown coal and lessive soil, associated with the secretion of extracellular enzymes, suggesting the presence of a degradative process performed by the fungus [16]. Furthermore, about $80 \%$ of humic acid removal associated with extracellular enzymatic activity was reached using Trametes versicolor and Phanerochaete chrysosporium on a synthetic solution prepared with $0.8 \%$ humic acid, through batch tests $[17,18]$. The authors indicated that the observed bioremediation process was due to a combination of biodegradation and biosorption $[17,18]$.

Despite the increasing interest toward the use of WRF as a potential bioremediation tool, processes based on fungal biomass are still poorly applied. Indeed, long-term operations of fungal bioreactors in non-sterile conditions have been demonstrated to be difficult to maintain [5]. This is mainly due to bacterial contamination, which results in competition for available organic substrates, negatively affecting WRF metabolism [19]. At the moment very little is known about the optimal operating conditions to enhance fungal bioremediation potential, such as fungal needs and responses to feeding and potential interferences on hyphal growth and fungal metabolism due to mixing or aeration [19]. This lack of knowledge may limit the scale-up of fungal-based processes. Indeed, several authors have reported low yields or slow processes depending on the design and operation of the reactor [19].

In this study, the efficiency of Bjerkandera adusta MUT 2295, previously selected for its decolorisation capability on a sample of landfill leachate from Italy [20], was tested against three effluent samples. This fungal strain, already reported as effective in the degradation and detoxification of textile, tannery, and pharmaceutical wastewaters [21,22], was evaluated in the treatment of raw landfill leachate (Canada) and, for the first time, on two synthetic wastewaters containing tannic and humic acids, which were selected as components of the recalcitrant fraction of landfill leachate [23-25]. In particular, several parameters, including $\mathrm{COD}$, color removals, and $\mathrm{MnP}$ activity, were measured in the three effluents to verify whether the selected strain could be exploited as a bioremediation tool for the target effluents' recalcitrant fraction.

\section{Materials and Methods}

\subsection{Fungal Strain}

Bjerkandera adusta MUT 2295 was obtained from the Mycotheca Universitatis Taurinensis Collection (MUT), University of Turin. This fungal strain was selected out of 12 strains due to its capability to treat raw leachates (Italy). Strain selection was performed through a biodegradation experiment in which decolorisation potential was used as the main criteria, in which B. adusta MUT 2295 was able to remove up to $40 \%$ of the color and produce MnP [20].

\subsection{Target Effluents}

The efficiency of the treatment with B. adusta was tested on a raw leachate collected from Brady Road landfill (Winnipeg, Canada) and two synthetic recalcitrant compound solutions prepared with tannic acid $(1.3 \mathrm{~g} / \mathrm{L})$ and humic acid $(1.5 \mathrm{~g} / \mathrm{L})$. Both compounds were chosen as representatives of landfill leachate recalcitrant fraction [23-25]. The solutions were prepared by adding the chemicals directly into deionized water, without the addition of nutrients or sterilization. Tannic and humic acids used in this study were of analytical grade and purchased from VWR Canada.

\subsection{Fungal Cultivation and Experimental Conditions}

B. adusta was cultured on Malt Extract Agar (MEA, $20 \mathrm{~g} / \mathrm{L}$ glucose, $20 \mathrm{~g} / \mathrm{L}$ malt extract, $20 \mathrm{~g} / \mathrm{L}$ agar, and $2 \mathrm{~g} / \mathrm{L}$ peptone) at $25{ }^{\circ} \mathrm{C}$ for one week (Figure $1 \mathrm{~A}$ ). After the cultivation, B. adusta was homogenized under aseptic conditions, with sterile saline $(9 \mathrm{~g} / \mathrm{L} \mathrm{NaCl})$ and inoculated into $1 \mathrm{~L}$ flasks containing glucose and yeast extract broth (GLY, $5 \mathrm{~g} / \mathrm{L}$ glucose, $1.9 \mathrm{~g} / \mathrm{L}$ yeast extract) and $2 \mathrm{~cm}^{3}$ 
polyurethane foam cubes (PUF); $1.5 \mathrm{~mL}$ of homogenate was added per cube. Flasks were incubated in agitation $(150 \mathrm{rpm})$ and at room temperature $\left(23 \pm 2{ }^{\circ} \mathrm{C}\right)$ for one week, in order to enable the immobilization of the fungus onto the cubes (Figure 1C). After 7 days, the cubes were removed from the broth to start the experiment with raw leachate and the two synthetic effluents. In particular, two immobilized cubes were added to $500 \mathrm{~mL}$ flasks containing $160 \mathrm{~mL}$ of effluent. Flasks were kept in agitation $(150 \mathrm{rpm})$ for ten days at room temperature $\left(23 \pm 2{ }^{\circ} \mathrm{C}\right)$. Trials were triplicated including the same number of controls, without fungal inoculum, for a total of 18 flasks. Glucose $(1.0 \mathrm{~g} / \mathrm{L}) \mathrm{was}$ added to the three effluents as fungal co-substrate for growth. The $\mathrm{pH}$ was adjusted to 4.5 using $10 \%$ sulphuric acid in raw leachate and humic acid and using $\mathrm{NaOH}(1.0 \mathrm{~N})$ for tannic acid. All the chemicals, used to prepare MEA and GLY and to adjust the solution $\mathrm{pH}$, were of analytical grade and purchased from VWR, Canada. Grab samples for the evaluation of treatment efficiency were collected after a few minutes and after 24, 48, 96, 168, and $240 \mathrm{~h}$ from the beginning of the test.
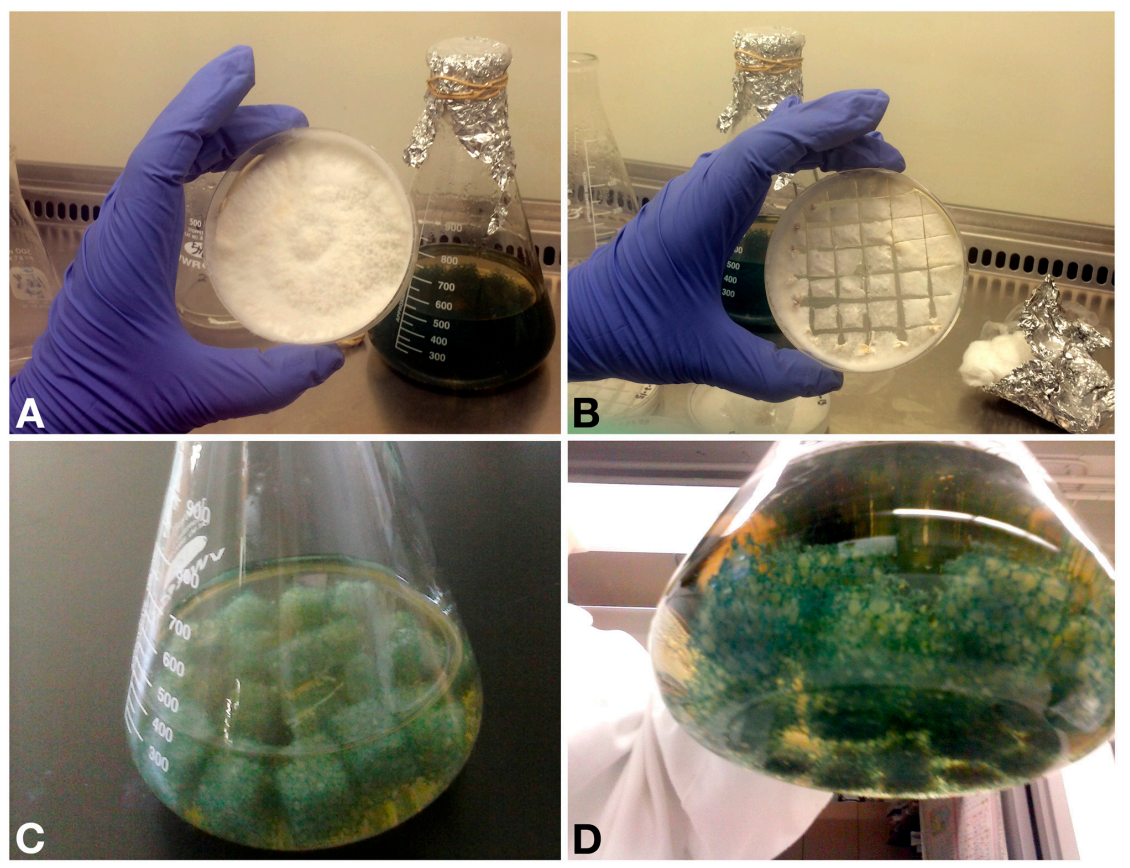

Figure 1. Fungal cultivation (A) and immobilization on polyurethane foam cubes (PUF) (B-D).

\subsection{Parameters for the Evaluation of Treatments' Efficiency}

Effluent $\mathrm{pH}$ was measured using Eutech $\mathrm{pH} 5^{+} \mathrm{pH}$-meter. Glucose was used as co-substrate for fungal growth and its concentration was measured during the first 3 days of treatment, according to the reducing sugar protocol [26]. COD removal, decolorisation, $\mathrm{MnP}$ activity, and $\mathrm{BOD}_{5}$ were used to evaluate the efficiency of the treatment. All these parameters, except $\mathrm{BOD}_{5}$, were measured after a few minutes and after 24, 48, 96, 168, and $240 \mathrm{~h}$ from the beginning of the test. COD was measured according to the Standard Methods for Examination of Water and Wastewater 20th edition Section 5220, Hach Spectrophotometric procedure (spectrophotometer DR2800) [27]. COD removal\% was calculated as follows:

$$
\% \text { CODremoval }=\left(\frac{\mathrm{COD}_{0 \mathrm{~h}}-\mathrm{COD}_{240 \mathrm{~h}}}{\mathrm{COD}_{0 \mathrm{~h}}}\right) \times 100
$$

$\mathrm{BOD}_{5}$ was measured at the beginning of the test, after glucose addition, and at the end of the treatment, according to Standard Methods for Examination of Water and Wastewater (SMEW, 20th Edition) [27].

The decolorisation percentage (DP) in raw leachate and the humic acid solution were determined spectrophotometrically as the decrease of the spectrum area (the integral of the absorbance spectrum) 
in the visible range (380-760 $\mathrm{nm}$ ) with respect to the unseeded control [21]. DP calculation is showed in Equation (2), in which the term $A_{\text {treat }}$ is the spectrum area of the trials inoculated with the fungus and the term $A_{\text {control }}$ refers to the spectrum area of the unseeded trials.

$$
\mathrm{DP}=100-\left(\frac{A_{\text {treat }} * 100}{A_{\text {control }}}\right)
$$

The removal of tannic acid solution was monitored spectrophotometrically as the decrease of the absorbance spectrum area in the UV range (200-380 $\mathrm{nm}$ ) with respect to the unseeded control, with particular attention to the peaks corresponding to tannic acid $(274 \mathrm{~nm})$ and gallic acid $(310 \mathrm{~nm})$.

The MnP activity was measured at $25{ }^{\circ} \mathrm{C}$, monitoring the oxidation at $590 \mathrm{~nm}$ of dimethylaminobenzoic acid/3-methyl-2-benzothiazoline hydrazone hydrocloride (DMAB/MBTH) in $0.1 \mathrm{M}$ succinate lactate buffer $\mathrm{pH} 4.5$ [28]. The enzymatic activity was calculated in international Units $(\mathrm{U})$, where 1 unit is defined as the amount of enzyme that oxidases $1 \mu$ mole of substrate per minute. The calculation of MnP activity is shown in Equation (3), whose terms can be explained as follows:

- $\Delta$ is the difference between the absorbance at $590 \mathrm{~nm}$ of the sample and the respective blank, which was performed without substrate addition;

- $V_{\text {sample }}$ is the volume $(\mu \mathrm{L})$ of the sample in the reaction mixture $(20 \mu \mathrm{L}), V_{\text {mixture }}$ is the total volume of the mixture $(100 \mu \mathrm{L})$;

- $\quad \varepsilon_{590}$ is the molar extinction coefficient for DMAB and MBTH. $\left(32,900 \mathrm{M}^{-1} \cdot \mathrm{cm}^{-1}\right)$.

$$
\mathrm{MnPU} / L=\left(\frac{\Delta * 1000 * V_{\text {sample }}}{\varepsilon_{590} * V_{\text {mixture }}}\right)
$$

Samples for ammonium nitrogen $\left(\mathrm{NH}_{4}{ }^{+}-\mathrm{N}\right)$, nitrites $\left(\mathrm{NO}_{2}{ }^{-}-\mathrm{N}\right)$, and nitrates $\left(\mathrm{NO}_{3}{ }^{-} \mathrm{N}\right)$ were previously filtered using Whatman Filter Papers Grade 1, and their concentrations were measured via a flow injection analyzer (Quick Chem 8500, LACHAT Instruments).

The dry weight of the fungal biomass was measured before starting the experiment, at the end of immobilization in GLY, and at the end of the experiment. To calculate the weight of fungal biomass inside a cube, the dry weight of a single empty cube was subtracted from each measurement. Empty cube dry weight was calculated as the average among three replicates. For each flask, two PUFs were used, for a total of two PUFs after the immobilization phase and 6 PUFs/condition at the end of the experiment. The dry weight was measured after overnight standing at $65{ }^{\circ} \mathrm{C}$. Dry weight increase was calculated as the difference between the dry weight of fungal biomass/flask at the end of the experiment and at the end of the immobilization phase.

At the end of the experiment, Total Suspended Solids (TSS) were measured in each flask, according to Standard Methods for Examination of Water and Wastewater (SMEW, 20th Edition) [27]. The total biomass was calculated at the end of the experiment as the sum of dry weight increase, expressed in $\mathrm{mg} / \mathrm{L}$, and TSS (mg/L).

\subsection{Statistical Analysis}

The data of COD and color removals were analyzed with the aid of a one-way Analysis of Variance (ANOVA), using STATISTICA 7.0 (StatSoft, Inc., Tulsa, OK, USA). Variance homogeneity was tested using Levene's Test. In case of $p<0.05$ (Levene Test), ANOVA was performed through Welch's Test.

\section{Results}

\subsection{Target Effluents Characterization}

Details of the raw leachate chemical characterization were as follows: $\mathrm{pH}$ 7.6, COD $1636 \pm 84$ (mg/L), ammonium nitrogen $704 \pm 202(\mathrm{mg} / \mathrm{L})$, phosphorus $3.36 \pm 0.98(\mathrm{mg} / \mathrm{L}), \mathrm{BOD}_{5} 150(\mathrm{mg} / \mathrm{L})$, 
and $\mathrm{BOD}_{5} / \mathrm{COD}$ ratio 0.091 . These characteristics suggest that the landfill leachate used in this study was old, with high refractory carbon load and high ammonium nitrogen concentration. After glucose addition, raw leachate COD was $2300 \pm 85$ (mg/L). Initial COD values of the two synthetic solutions that simulate raw leachate in terms of organic load were $1630 \pm 9$ and $1740 \pm 37(\mathrm{mg} / \mathrm{L})$ before glucose addition and $2545 \pm 84$ and $2580 \pm 95(\mathrm{mg} / \mathrm{L})$ after glucose addition in tannic acid and humic acid solution, respectively.

\section{2. $p H$ Values}

In the trials inoculated with $B$. adusta, the average value of effluent $\mathrm{pH}$ was $5.07 \pm 1.03$ with a minimum value of 4.17 and a maximum of 7.78. In the unseeded controls, the average $\mathrm{pH}$ value was $4.57 \pm 0.45$ with minimum value of 4.07 and maximum of 5.34 (Figure 2). These results indicated higher $\mathrm{pH}$ stability in unseeded controls compared to the trials inoculated with the selected fungal strain, in which a gradual $\mathrm{pH}$ increase could be observed starting from $96 \mathrm{~h}$ from the beginning of the experiment. In particular, in raw leachate trials $\mathrm{pH}$ increased from $4.75 \pm 0.03$ at $48 \mathrm{~h}$ to $5.79 \pm 0.015$ at $96 \mathrm{~h}$, reaching a final value of $7.78 \pm 0.04$ at the end of the experiment $(240 \mathrm{~h})$. In those flasks containing humic acid, $\mathrm{pH}$ rise could be observed only in the last measurement ranging from $4.88 \pm 0.20$ at $168 \mathrm{~h}$ and $6.26 \pm 0.54$ at $240 \mathrm{~h}$.

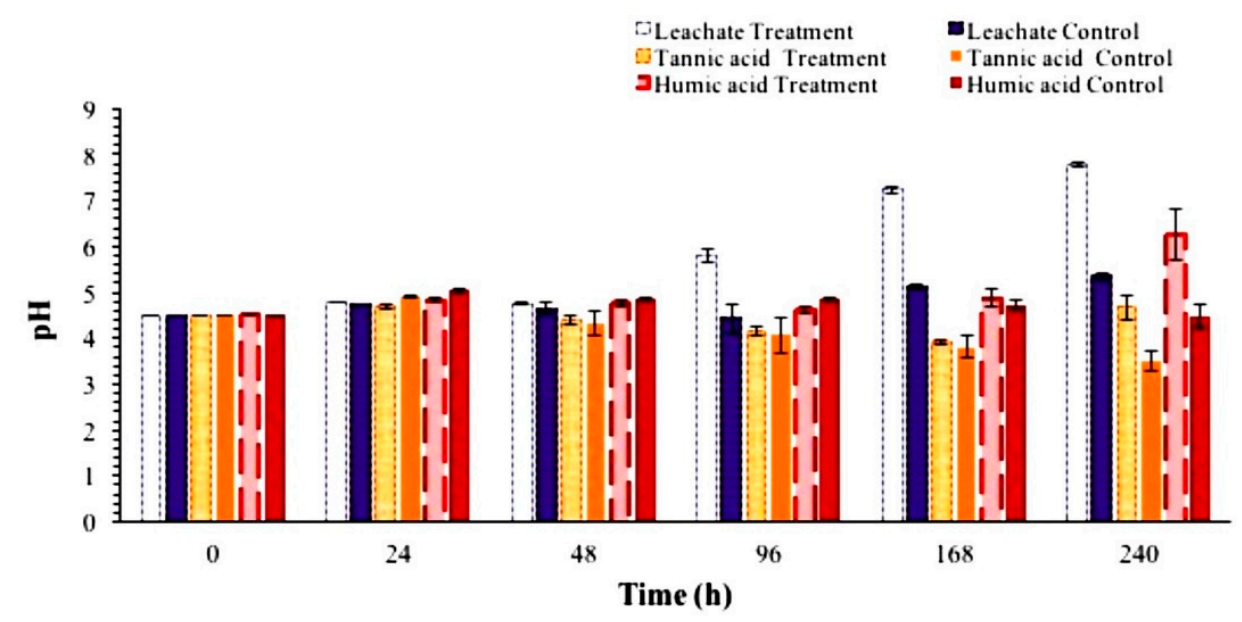

Figure 2. Effluents $\mathrm{pH}$ values during the treatment given as the average among trials; error bars indicate the Standard Deviations (SD) of the three replicates.

\subsection{Glucose Consumption and Biological Oxygen Demand $\left(B O D_{5}\right)$ Removal}

Consumption of glucose, co-substrate for fungal growth, was measured after 3 days from the beginning of the experiment. As shown in Table 1, average glucose consumption percentage was $60 \pm 5.63$ in the trials inoculated with B. adusta, with a minimal consumption of $54 \%$ in tannic acid trials and a maximum one of $65 \%$ in raw leachate. The results showed $5 \%$ and $12 \%$ of glucose consumption in the controls of humic acid and tannic acid solutions, respectively. On the contrary, $66 \%$ of glucose consumption was detected in raw leachate control, suggesting the presence of autochthonous microorganisms capable of using glucose as carbon source.

In Table 1, the results of $\mathrm{BOD}_{5}$ removals in the three effluents at the end of the treatment are shown. BOD $_{5}$ removal was complete in raw leachate and $89 \%$ and $75 \%$ in tannic acid and humic acid solutions, respectively. In the case of raw leachate, the initial $\mathrm{BOD}_{5}$ value of $150 \mathrm{mg} / \mathrm{L}$ was fully removed, implying the complete removal of leachate biodegradable organic matter and total glucose consumption. In the two synthetic solutions, $11 \%$ and $25 \%$ of $\mathrm{BOD}_{5}$ was detected at the end of the treatment, which is attributable to residual glucose or a possible increase in the biodegradability (as $\mathrm{BOD}_{5} / \mathrm{COD}$ ) of the effluents, due to the fungal treatment. Further investigations, such as respirometric tests, could clarify this point. 
Table 1. Biological Oxygen Demand $\left(\mathrm{BOD}_{5}\right)$ concentration in the three effluents at the beginning of the test (after glucose addition), at the end of the treatment $(240 \mathrm{~h})$, and BOD 5 removal (\%) between 0 and $240 \mathrm{~h}$. Glucose concentration at the beginning of the test, at $96 \mathrm{~h}$, and glucose consumption (\%) measured against the different effluents during the test. Values are given as the average among triplicates. Bars indicated Standard Deviations (SD) T: trials inoculated with B. adusta; C; controls. RL: Raw Leachate; TA: Tannic Acid and HU: Humic acid.

\begin{tabular}{|c|c|c|c|c|c|c|c|c|c|}
\hline \multirow[b]{2}{*}{ Trial } & \multirow[b]{2}{*}{ Effluent } & \multirow{2}{*}{$\begin{array}{c}\text { Beginning }(0 \mathrm{~h}) \\
\text { BOD }_{5} \mathrm{mg} / \mathrm{L}\end{array}$} & \multicolumn{2}{|c|}{ End of the Experiment $(240 \mathrm{~h})$} & \multicolumn{2}{|c|}{ Beginning (0 h) } & \multicolumn{3}{|c|}{$96 \mathrm{~h}$} \\
\hline & & & $\mathrm{BOD}_{5} \mathrm{mg} / \mathrm{L}$ & $\begin{array}{c}\text { BOD }_{5} \\
\text { Removal (\%) }\end{array}$ & Glucose mg/L & SD & Glucose mg/L & SD & $\begin{array}{c}\text { Glucose } \\
\text { Removal (\%) }\end{array}$ \\
\hline \multirow{3}{*}{$\mathrm{T}$} & RL & 840 & $<40$ & 100 & 933 & 293.79 & 329 & 6.053 & 65 \\
\hline & $\mathrm{TA}$ & 720 & 80 & 89 & 1140 & 201.09 & 527 & 7.176 & 54 \\
\hline & HA & 770 & 190 & 75 & 1286 & 193.78 & 494 & 106.85 & 62 \\
\hline \multirow{3}{*}{ C } & RL & n.a & n.a & n.a & 974 & 154.49 & 336 & 10.53 & 66 \\
\hline & $\mathrm{TA}$ & n.a & n.a & n.a & 1444 & 56.28 & 1265 & 233.62 & 12 \\
\hline & HA & n.a & n.a & n.a & 1483 & n.a. & 1406 & 66.67 & 5 \\
\hline
\end{tabular}

Note: n.a: data not available.

\subsection{Chemical Oxygen Demand (COD) Removal}

COD removal in the three effluents after 10 days from the inoculation of B. adusta MUT 2295 is reported in Table 2. The results showed COD removals of $48 \%$, in the trials with raw leachate and humic acid and $61 \%$ in those containing tannic acid.

As glucose represented about 36-39\% of effluent's COD, assuming its complete depletion at the end of the experiment, the detected COD removal percentages were higher than glucose consumption in all the samples inoculated with B. adusta. A significant difference in the COD values, between treatments inoculated with $B$. adusta and the respective unseeded controls, was found in the trials with humic acid $(p=0.22, F=7.22)$ and tannic acid $(p \leq 0.001)$, respectively. In the case of raw leachate and humic acid, the data met the assumption of the homogeneity of the variance (Levene's Test), with $p=0.326$ and $p=0.148$. On the contrary, in the case of tannic acid, the assumption of variance homogeneity was not fulfilled $(p=0.006)$. For this reason the results of tannic acid removal were analyzed using the Welch's Test and achieving $p<0.001$. The maximum COD removal was achieved in the trials containing tannic acid, with a final COD value of $992 \pm 26.62 \mathrm{mg} / \mathrm{L}$ and $61 \%$ of COD decrease with respect to the initial value, while only $6 \%$ COD removal was found in the respective unseeded controls (Table 2 and Figure 3). Although significant differences between treatments and controls were detected in both synthetic solutions, the COD removal observed in the trials containing humic acid and inoculated with B. adusta was presumably due to glucose consumption. The difference in the COD removal between treatments and controls was 33\%, which was lower than the organic load represented by glucose (37\%). A similar pattern could be observed in raw leachate trials, in which the percentage of COD removal (48\%) was the same in the treatments, inoculated with B. adusta, and in the respective unseeded controls.

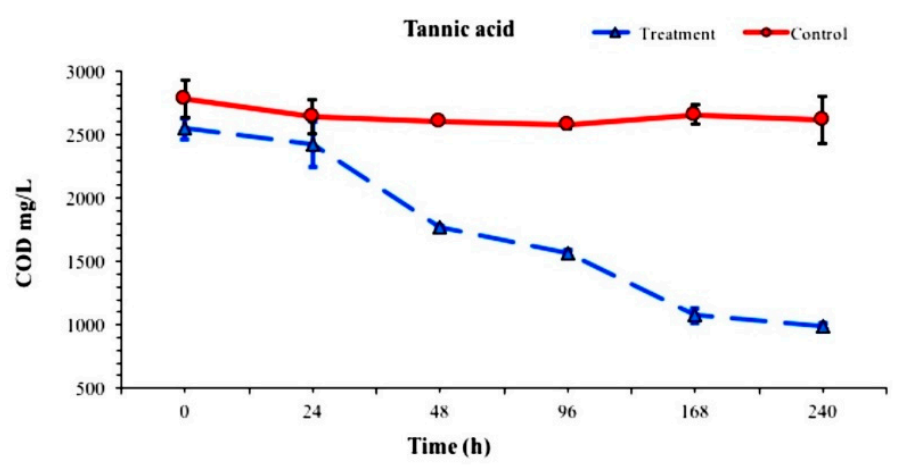

Figure 3. Chemical Oxygen Demand (COD) values as $\mathrm{mg} / \mathrm{L}$ in tannic acid trials during the experiment. Values are given as the average among triplicates. Bars indicated Standard Deviations (SD). 
Table 2. Chemical Oxygen Demand (COD) values (mg/L) at the beginning of the experiment $(0 \mathrm{~h})$, at the end experiment $(240 \mathrm{~h})$, and COD removal percentage $(0-240 \mathrm{~h})$. Values were given as average among triplicates $\pm \mathrm{SD}$. ${ }^{*}$ indicates $p \leq 0.05,{ }^{* *} p \leq 0.01$, and ${ }^{* * *} p \leq 0.001$, one-way Analysis of Variance (ANOVA), difference between the treatment, and the respective unseeded controls.

\begin{tabular}{ccccccc}
\hline \multirow{2}{*}{ Trial } & \multirow{2}{*}{ Effluent } & \multicolumn{2}{c}{ Beginning $\mathbf{( 0 ~ h )}$} & \multicolumn{2}{c}{ End of the Experiment (240 h) } \\
\cline { 3 - 7 } & & COD mg/L & SD & COD mg/L & SD & COD Removal (\%) \\
\hline \multirow{3}{*}{ Treatments } & Raw Leachate & 2365 & 82.82 & 1185 & 80.11 & 48 \\
& Tannic Acid ** & 2545 & 82.74 & 992 & 26.65 & 61 \\
& Humic acid * & 2580 & 94.76 & 1346 & 27.07 & 48 \\
\hline \multirow{3}{*}{ Controls } & Raw Leachate & 2747 & 451.55 & 1399 & 33.62 & 48 \\
& Tannic Acid & 2780 & 142.32 & 2610 & 185.33 & 6 \\
& Humic acid & 2758 & 47.38 & 2336 & 424.09 & 15 \\
\hline
\end{tabular}

\subsection{Color Removal}

As shown in Figure 4a, B. adusta decolorized raw leachate, humic acid, and tannic acid solutions up to $49 \%, 42 \%$, and $25 \%$ after one week of treatment, respectively. The results of raw leachate and humic acid met the assumption of homogeneity of the variance (Levene test), with $p=0.101$ and $p=0.074$ in raw leachate and humic acid, respectively. On the contrary, tannic acid results did not meet the homogeneity assumption $(p=0.006)$ and were analyzed using Welch's test. In the case of dark colored effluents (raw leachate and humic acid solution), differences in the spectrum area toward respective unseeded controls were significant after $96 \mathrm{~h}$ and highly significant after $168 \mathrm{~h}$ of treatment (Figure 5a,b). In particular, in raw leachate $p=0.24(F=8.30)$ after $96 \mathrm{~h}$ and $p=0.009(F=11.54)$ after $168 \mathrm{~h}$, while in humic acid $p=0.04(F=7.57)$ after $96 \mathrm{~h}$ and $p=0.008(F=12.38)$ after $168 \mathrm{~h}$.

In the tannic acid solution, initially almost colorless, a first increase in the spectrum area occurred within the first $48 \mathrm{~h}$ from the beginning of the experiment. Then, a reduction up to $25 \%$, associated with highly significant differences toward respective unseeded controls, was observed in the trials inoculated with B. adusta (Figure $4 \mathrm{a}, \mathrm{c}$ ). Indeed, the spectra of these trials, after $96 \mathrm{~h}$, were characterized by an evident flattening of the shape compared to the respective unseeded controls for the same duration. In addition, at $168 \mathrm{~h}$, the spectra of treatment trials showed 33\% and 38\% reductions at $310 \mathrm{~nm}$ and $260 \mathrm{~nm}$, respectively.

\subsection{Enzymatic Activities}

As shown in Figure 5, MnP activity was detected in all the treatments, confirming that B. adusta was metabolically active during the experiment.

The maximum value was reached in the tannic acid solution after $72 \mathrm{~h}$ with $8.9 \pm 2.3 \mathrm{U} / \mathrm{L}$, in correspondence to the beginning of spectrum area reduction. In the case of raw leachate, the maximum value of $\mathrm{MnP}$ was $1.92 \pm 1.4 \mathrm{U} / \mathrm{L}$, after $72 \mathrm{~h}$ from the beginning of the experiment. In the trials containing humic acid, a maximum $\mathrm{MnP}$ value of $5.6 \pm 1.5 \mathrm{U} / \mathrm{L}$ was found after $120 \mathrm{~h}$ from the beginning of the test.

\subsection{Fungal Dry Weight and TSS}

In Figure 6, the results of fungal dry weight increase and TSS at the end of the experiment are shown.

At the end of the experiment, the average biomass increase detected in the three effluents was $60 \mathrm{mg} /$ flask \pm 3.7 , with a maximum value of $64 \mathrm{mg}$ detected in humic acid trials and a minimum value of $56 \mathrm{mg}$, detected in the ones containing tannic acid.

The lowest TSS concentration was detected in tannic acid trials with $2.25 \pm 0.63 \mathrm{mg} / \mathrm{L}$ of TSS, while $2.35 \pm 1.62 \mathrm{mg} / \mathrm{L}$ were measured in raw leachate and $10.95 \pm 2.05 \mathrm{mg} / \mathrm{L}$ in humic acid trials.

The total biomass was $375 \mathrm{mg} / \mathrm{L}$ in raw leachate, $353 \mathrm{mg} / \mathrm{L}$ in tannic acid, and $409 \mathrm{mg} / \mathrm{L}$ in humic acid trials. 
(a)

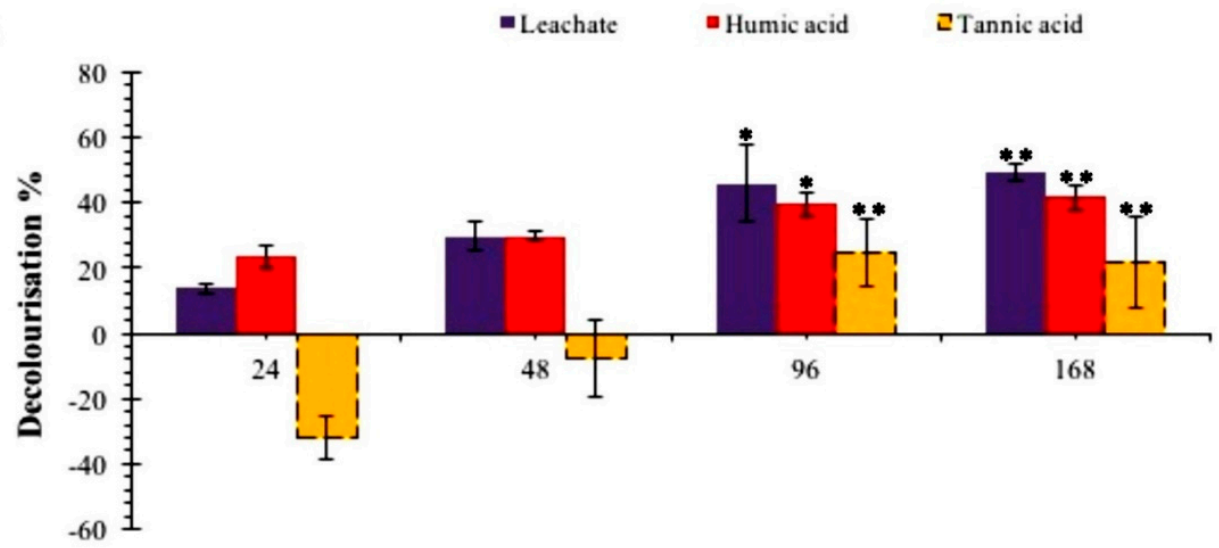

Hours

(b)

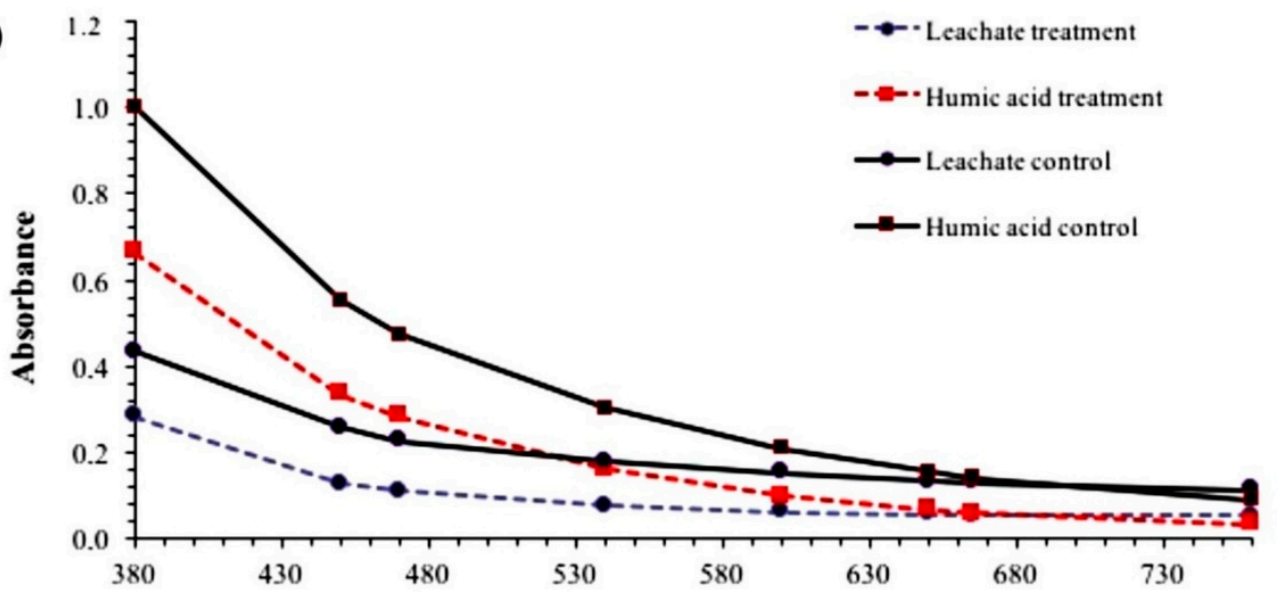

Wavelenght (nm)

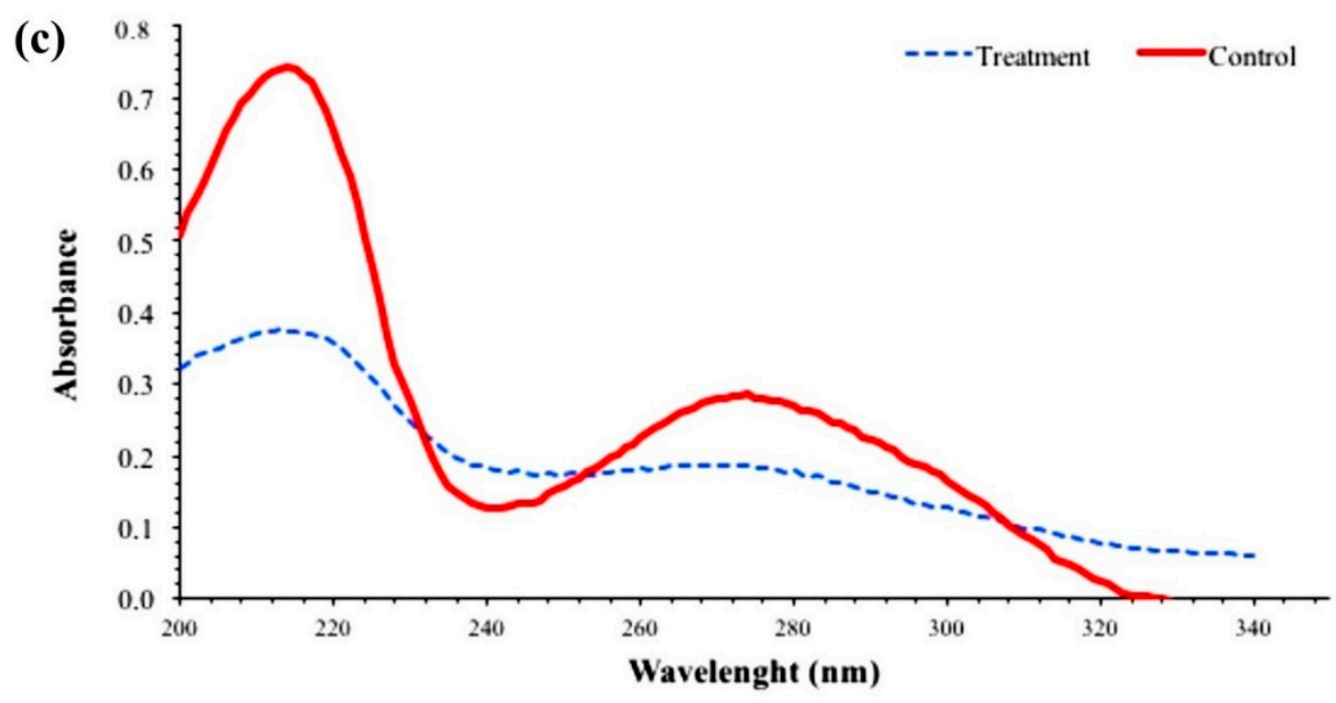

Figure 4. (a) Effluent decolorisation percentages, calculated toward respective unseeded controls, in one week of treatment. Error bars indicate Standard Deviation (SD); (b) spectrum area reduction in raw leachate and humic acid after $168 \mathrm{~h}$; and (c) spectrum area reduction in tannic acid after $96 \mathrm{~h}$. Decolorisation values are given as the average among triplicates with SD (+). Negative values should be considered as increases in the spectrum area. * indicates $p \leq 0.05$ and ${ }^{* *} p \leq 0.01$ (one-way ANOVA, difference between the treatments, trials, and the respective unseeded controls). 


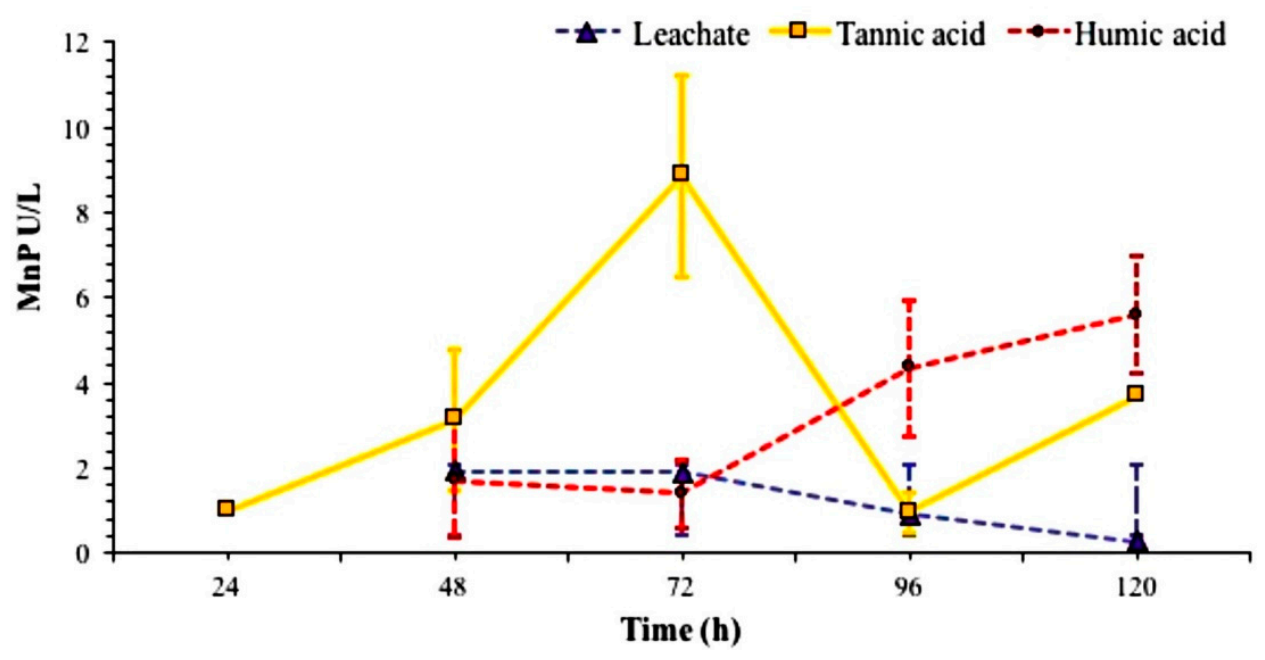

Figure 5. Manganese peroxidases $(\mathrm{MnP})$ production during the treatment. Values are given as the average among triplicates + Standard Deviation (SD).

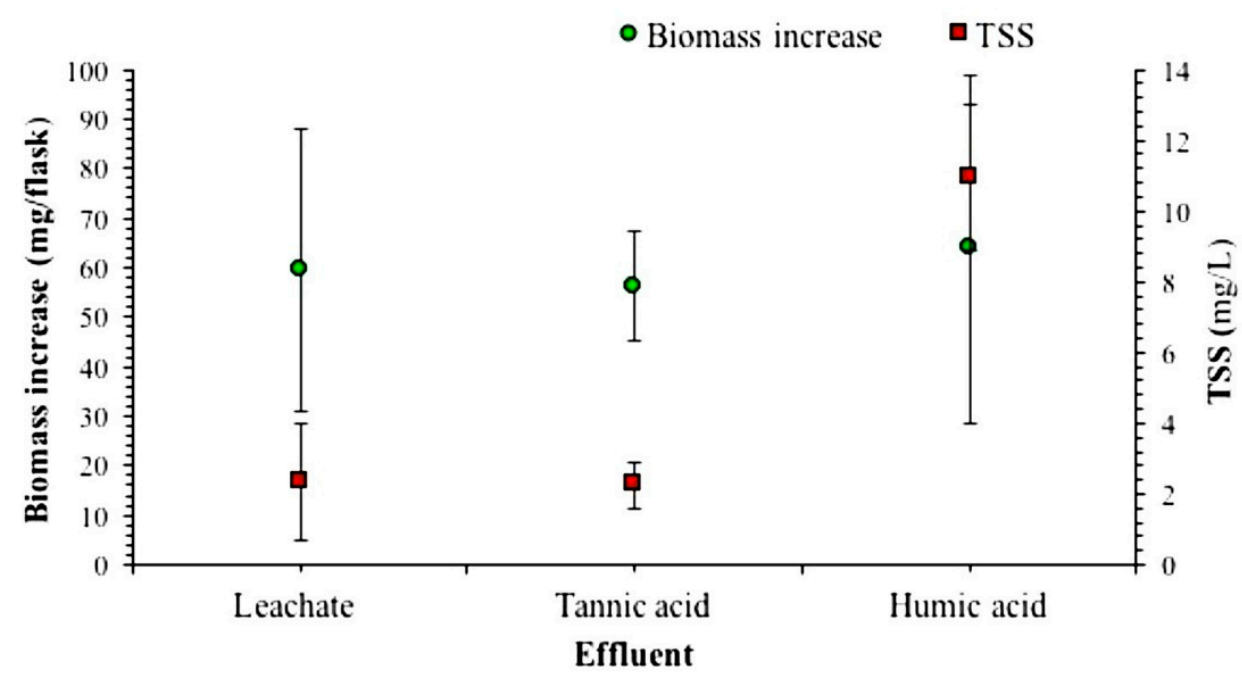

Figure 6. Circles represent biomass increase as mg/flask. Squares represent Total Suspended Solids (TSS) as $\mathrm{mg} / \mathrm{L}$. All the values are given as average among triplicates. Bars indicated Standard Deviations (SD).

\section{Discussion}

In this study the efficiency of B. adusta MUT 2295, grown on PUFs, was tested toward raw leachate and two synthetic recalcitrant solutions prepared with tannic and humic acids. Although high variability was found in landfill leachate composition, the chemical characterization of the leachate used in this study is typical of mature and high refractory landfill leachate [3].

The results suggested active fungal metabolism during the whole experiment. In particular, all the $\mathrm{pH}$ values, measured during the tests, were compatible with fungal active metabolism [29]. The increasing trend of the treatment $\mathrm{pH}$ values could indicate that $B$. adusta buffered the effluents at $\mathrm{pH}$ values as close as possible to the optimum range for the enzymes involved in the process. It is known that many enzymes, including peroxidases, have an optimum $\mathrm{pH}$ between 5 and 6 [29]. In addition, Kaushik and Malik [30] had already described WRF buffering capacity. However, considering that $\mathrm{pH}$ increased at $96 \mathrm{~h}$ only in the leachate treatment, a possible decline of B. adusta active metabolism in leachate trials could not be excluded. It is reasonable to hypothesize that the full co-substrate consumption could have negatively affected the metabolism of the fungus or its capability to compete 
with the autochthonous organisms. The same pattern could not be observed in the synthetic effluents. Indeed, an increase in the $\mathrm{pH}$ values of the humic acid treatment was detected only at the end of the treatment and no important increases were detected in $\mathrm{pH}$ values of the tannic acid treatment (Figure 2).

Significant (61\%) COD removals have been achieved in tannic acid trials. In particular, considering that COD removal in the trials containing tannic acid and inoculated with B. adusta was higher than glucose organic load (37\%) and the low COD removals in the respective controls, it is evident that a degradative process occurred in the presence of the selected fungal strain. According to our knowledge, this is the first report about tannic acid COD removal, achieved using the selected fungal strain, B. adusta MUT 2295.

On the other hand, the same conclusions could not be drawn for the other two effluents tested in this study. The results achieved in raw leachate and humic acid suggest that the presence of fungal biomass could have led to possible degradative processes, which were not detectable through total COD measurements, such as increases in the biodegradable COD (bCOD) fraction, as previously reported by other authors for the fungal treatment of industrial effluents [31]. Besides the lack of evident COD decreases in raw leachate and humic acid trials that were activated by the presence of the fungus, different rearrangements of the chemical structures of recalcitrant compounds and consequent enhancement of their bioavailability for other organisms, which were related to the treatment with B. adusta, could not be excluded. Since humic acid and tannic acid are considered part of leachate natural recalcitrant fraction [24,25], the lack of evident COD decreases, due to a degradative process in humic treatment, is in accordance with the pattern observed in raw leachate trials. The high removal detected in tannic acid trials could be explained considering that tannic acid is an hydrolysable tannin, which would start degrading in the early phase of leachate lifecycle where the biodegradable organic matter is also utilized by microorganisms [3]. Since the landfill leachate used in this study presents the typical characterization of mature landfill leachate with the low $\mathrm{BOD}_{5} / \mathrm{COD}$ ratio [2], it is reasonable to expect that the concentration of refractory condensed tannins was higher than that of hydrolysable ones.

Color removal was observed in all the effluents treated with B. adusta. However, only in the case of tannic acid trials, spectrum area reductions were positively related with significant COD removals. Furthermore, in tannic acid trials inoculated with B. adusta MUT 2295, an evident flattening of the tannic acid spectrum occurred, associated with the reduction of the absorbance at 310 and $260 \mathrm{~nm}$, which indicated the removal of tannic and gallic acids [32]. All these results provided further evidence of the degradative process activated by B. adusta toward tannic acid.

The color removal observed in the three effluents was not positively associated with high enzymatic activity. Indeed, limited concentrations of $\mathrm{MnP}$ were detected during the experiment.

In the case of tannic acid, this result could be explained considering that other enzymes could be involved in the degradative process observed during the experiment. Although several enzymes, including tannases, laccases, and peroxidases, are capable of degrading tannins [32], the observation of the spectra suggested a possible involvement of tannase. This enzyme catalyzes the depolymerisation of gallotannins producing gallic acid and glucose [32]. Hence, further analyses are needed to clarify the role of tannase in the observed degradation in tannic acid trials inoculated with B. adusta MUT 2295.

In the case of raw leachate, the maximum value of MnP of $1.92 \pm 1.4 \mathrm{U} / \mathrm{L}$ was similar to the activity reported by Kalčikova et al. [3] in 100\% mature landfill leachate. Although peroxidases have been described as the major enzymes involved in the decolorisation of leachate [10], the values observed were not positively associated with the spectra reduction of $49 \%$. Our results were in accordance with those achieved by Anastasi et al. [33] that reported the lack of relation between enzymatic activity and color removal. The authors attributed the observed pattern to several possible reasons, including rapid enzymatic inactivation and presence of enzymatic isoforms with different substrate affinity. In this case, as suggested by the $\mathrm{pH}$ increase at $96 \mathrm{~h}$, a possible decline of $B$. adusta, due to other microorganism competition or leachate high toxicity, could explain this result. On the other hand, further analyses would be necessary to explain the results achieved in raw leachate trials. Indeed, the low MnP activity 
observed could be due to the lack of a degradative process in those trials. According to this hypothesis, the detected COD removal could be explained by the biosorption of pigments to fungal biomass or, alternatively, by the presence of autochthonous microorganisms capable of removing a certain amount of recalcitrant compounds from the leachate itself [21].

The activity detected in humic acid trials was significantly lower compared to the results reported by others authors, which performed longer experiments with WRF on humic acid substances $[17,18,34]$. However, considering the increasing trend in $\mathrm{MnP}$ activity observed at the end of our experiment in humic acid trials, further investigations are needed to assess a possible relation with the detected color removal.

The values of biomass increase were similar to those reported by other authors in similar conditions. In particular, Saetang and Babel [13] detected a biomass increase between 51 and $66 \mathrm{mg} / \mathrm{PUF}$, using glucose as co-substrate and concentrated leachate. In our study, the increase was similar in the three effluents, suggesting that the fungus was able to grow in all the tested conditions, providing further evidence of the versatility of this strain, as reported by Anastasi et al. [21]. However, the lower values of Standard Deviation (SD) observed in the tannic acid trials, compared to raw leachate and humic acid ones, suggested higher stability of biomass in the tannic acid trials, which could be presumably associated with lower biomass loss from the cubes.

The TSS results provided further evidence of biomass stability in tannic acid trials in which the lowest TSS concentration was found, associated with a negligible SD. Although TSS could represent either biomass loss from the cubes or biomass growth that exceeded from the cube surface, considering the full pattern of results achieved in tannic acid trials our understanding is that the growth was homogeneous among replicates in tannic acid trials and only a negligible biomass loss occurred during the treatment. On the contrary, considering the full pattern of results in raw leachate and humic acid, we cannot exclude that, in several cubes, a partial biomass loss occurred.

All the results achieved at the end of the treatment confirmed the presence of a degradative process in the tannic acid trials inoculated with B. adusta. In addition, several results, such as spectrum analyses and the low $\mathrm{MnP}$ activity observed, suggested the presence of tannase, which are continuously needed for diverse industrial purposes, including tannery effluents treatment [35]. Although other authors [32] described tannic acid degradation by fungi, according to our understanding, this is the first report about tannic acid degradation by B. adusta MUT 2295 . These preliminary results could represent the first step for continuous experiments on wider scale aiming at optimizing process performances with the selected fungal strain.

\section{Conclusions}

Bjerkandera adusta MUT 2295 was metabolically active during the experiment. The treatment with the selected strain resulted in $49 \%, 25 \%$, and $42 \%$ of color removal in raw leachate, tannic acid, and humic acid, respectively. $\mathrm{BOD}_{5}$ was completely removed in raw leachate, while $89 \%$ and $75 \%$ of removal occurred in tannic and humic acid solutions, respectively. In all the trials, biomass increase equal to $60 \pm 3.7 \mathrm{mg} /$ flask in the three effluents was detected at the end of the treatment. This indicates the ability of the fungus to grow in all the tested conditions while overcoming the recalcitrance of the chemicals used and its competitive nature against other microorganisms in the raw leachate trials.

In the case of tannic acid, the process is associated with $61 \%$ of COD removal and the quantification of $\mathrm{MnP}$ activity, indicating the presence of tannic acid biodegradation in the trials inoculated with B. adusta. This is the first published record of effective treatment with Bjerkandera adusta MUT 2295 towards tannic acid. These results encourage the use of the selected fungal strain toward effluents containing tannic acid, which could be exploited using larger volumes and for longer durations to discern a deeper understanding of the process. Further investigations could also assess possible degradative processes in raw leachate and humic acid. 
Acknowledgments: This study was supported by MIUR with the FIR project (RBFR13V3CH_002) and by the EU Marie Curie Irses Program with the Carbala Project (PIRSES-GA-2011). Simone Gabrielli is gratefully acknowledged for his help in graphical artwork.

Author Contributions: Alessandra Bardi and Giulio Munz conceived and designed the experiments; Alessandra Bardi performed the experiments; Valeria Tigini, Federica Spina, Giovanna Cristina Varese, Alessandra Bardi, and Francesco Spennati selected the fungal strain used during the study. Alessandra Bardi analyzed the data; Simone Becarelli and Federica Spina helped in enzymatic and spectra analyses. The experiment was performed in the laboratory of Qiuyan Yuan that contributed reagents/materials/analysis tools; Alessandra Bardi wrote the paper. Giulio Munz, Giulio Petroni, Qiuyan Yuan, and Simona Di Gregorio revised and improved the manuscript.

Conflicts of Interest: The authors declare no conflict of interest and no role of the funding sponsors in the design of the study; in the collection, analyses, or interpretation of data; in the writing of the manuscript, or in the decision to publish the results.

\section{References}

1. Alexander, M. Biodegradation: Problems of molecular recalcitrance and microbial fallibility. Adv. Appl. Microbiol. 1965, 7, 35-80. [PubMed]

2. Kamaruddin, M.A.; Yusoff, M.S.; Aziz, H.A.; Hung, Y.T. Sustainable treatment of landfill leachate. Appl. Water Sci. 2015, 5, 113-126. [CrossRef]

3. Kalčíková, G.; Babič, J.; Pavko, A.; Gotvajn, A.Ž. Fungal and enzymatic treatment of mature municipal landfill leachate. Waste Manag. 2014, 34, 798-803. [CrossRef] [PubMed]

4. Ellouze, M.; Aloui, F.; Sayadi, S. Performance of biological treatment of high-level ammonia landfill leachate. Environ. Technol. 2008, 29, 1169-1178. [CrossRef] [PubMed]

5. Gullotto, A.; Lubello, C.; Mannucci, A.; Gori, R.; Munz, G.; Briganti, F. Biodegradation of naphthalenesulphonate polymers: The potential of a combined application of fungi and bacteria. Environ. Technol. 2015, 36, 538-545. [CrossRef] [PubMed]

6. Ellouze, M.; Sayadi, S. White-rot fungi and their enzymes as a biotechnological tool for xenobiotic bioremediation. In Management of Hazardous Wastes; InTech: Rijeka, Croatia, 2016.

7. Ghosh, P.; Thakur, I.S.; Kaushik, A. Bioassays for toxicological risk assessment of landfill leachate: A review. Ecotoxicol. Environ. Saf. 2017, 141, 259-270. [CrossRef] [PubMed]

8. Swati, V.; Ghosh, P.; Thakur, I.S. An integrated approach to study the risk from landfill soil of Delhi: Chemical analyses, in vitro assays and human risk assessment. Ecotoxicol. Environ. Saf. 2017, 143, 120-128. [CrossRef] [PubMed]

9. Ellouze, M.; Aloui, F.; Sayadi, S. Effect of high ammonia concentrations on fungal treatment of Tunisian landfill leachates. Desalination 2009, 246, 468-477. [CrossRef]

10. Tigini, V.; Spina, F.; Romagnolo, A.; Prigione, V.; Varese, G.C. Effective biological treatment of landfill leachates by means of selected white rot fungi. Chem. Eng. Trans. 2013, 32, 265-270.

11. Awasthi, A.K.; Pandey, A.K.; Khan, J. Potential of fungus Trichoderma harzianum for toxicity reduction in municipal solid waste leachate. Int. J. Environ. Sci. Technol. 2017, 1-8. [CrossRef]

12. Ghosh, P.; Thakur, I.S. Biosorption of landfill leachate by Phanerochaete sp. ISTL01: Isotherms, kinetics and toxicological assessment. Environ. Technol. 2016, 38, 1800-1811. [CrossRef] [PubMed]

13. Saetang, J.; Babel, S. Effect of leachate loading rate and incubation period on the treatment efficiency by Trametes versicolor immobilized on foam cubes. Int. J. Environ. Sci. Technol. 2009, 6, 457-466. [CrossRef]

14. Ghosh, P.; Swati, V.; Thakur, I.S. Enhanced removal of COD and color from landfill leachate in a sequential bioreactor. Bioresour. Technol. 2014, 170, 10-19. [CrossRef] [PubMed]

15. Bardi, A.; Yuan, Q.; Siracusa, G.; Chicca, I.; Islam, M.; Spennati, F.; Tigini, V.; Di Gregorio, S.; Levin, D.B.; Petroni, G.; et al. Effect of cellulose as co-substrate on old landfill leachate treatment using white-rot fungi. Bioresour. Technol. 2017, 241, 1067-1076. [CrossRef] [PubMed]

16. Belcarz, A.; Ginalska, G.; Kornillowicz-Kowalska, T. Extracellular enzyme activities of Bjerkandera adusta R59 soil strain, capable of daunomycin and humic acids degradation. Appl. Microbiol. Biotechnol. 2005, 68, 686-694. [CrossRef] [PubMed]

17. Zahmatkesh, M.; Spanjers, H.; Toran, M.J.; Blánquez, P.; van Lier, J.B.M.J. Bioremoval of humic acid from water by white rot fungi: Exploring the removal mechanisms. AMB Express. 2016, 6, 118. [CrossRef] [PubMed] 
18. Zahmatkesh, M.; Spanjers, H.; van Lier, J.B. A novel approach for application of white rot fungi in wastewater treatment under nonsterile conditions: Immobilization of fungi on sorghum. Environ. Technol. 2017, 1-11. [CrossRef] [PubMed]

19. Spina, F.; Romagnolo, A.; Prigione, V.; Varese, G.C. A Scaling-up issue: The optimal bioreactor configuration for effective fungal treatment of textile wastewaters. Chem. Eng. Trans. 2014, 38, 37-42.

20. Bardi, A.; Tigini, V.; Spina, F.; Varese, G.C.; Spennati, F.; Di Gregorio, S.; Petroni, G.; Yuan, Q.; Munz, G. Treatment of raw leachate and synthetic recalcitrant compounds using a selected white rot fungus. In Proceedings of the Sidisa 2016, X International Symposium on Sanitary and Environmental Engineering, Roma, Italy, 19-23 June 2016.

21. Anastasi, A.; Spina, F.; Prigione, V.; Tigini, V.; Giansanti, P.; Varese, G.C. Scale-up of a bioprocess for textile wastewater treatment using Bjerkandera adusta. Bioresour. Technol. 2010, 101, 3067-3075. [CrossRef] [PubMed]

22. Spina, F.; Anastasi, A.; Prigione, V.; Tigini, V.; Varese, G.C. Biological treatment of industrial wastewaters: A fungal approach. Chem. Eng. Trans. 2012, 27, 175-180.

23. Klein, K.; Kivi, A.; Dulova, N.; Zekker, I.; Mölder, E.; Tenno, T.; Trapido, M.; Tenno, T. A pilot study of three-stage biological-chemical treatment of landfill leachate applying continuous ferric sludge reuse in Fenton-like process. Clean Technol. Environ. Policy 2017, 19, 541-551. [CrossRef]

24. Renou, S.; Givaudan, J.G.; Poulain, S.; Dirassouyan, F.; Moulin, P. Landfill leachate treatment: Review and opportunity. J. Hazard. Mater. 2008, 150, 468-493. [CrossRef] [PubMed]

25. Baig, S.; Thiéblin, E.; Zuliani, F.; Jenny, R.; Coste, C. Landfill leachate treatment: Case studies. In Proceedings of the International Conference on Ozonation and Related Oxidation Process in Water and Waste Treatment, Berlin, Germany, 21-23 April 1997.

26. Miller, G.L. Use of dinitrosalicylic acid reagent for determination of reducing sugar. Anal. Chem. 1959, 31, 426-428. [CrossRef]

27. APHA (American Public Health Association). Standard Methods for the Examination of Water and Wastewater, 20th ed.; American Public Health Association: Washington, DC, USA, 1998.

28. Vyas, V.; Šašek, J. Effects of temperature on the production of manganese peroxidase and lignin peroxidase by Phanerochaete chrysosporium. Folia Microbiol. 1994, 39, 19-22. [CrossRef]

29. Ren, Y.; Yuan, Q. Fungi in landfill leachate treatment process. In Biodegradation and Bioremediation of Polluted Systems-New Advances and Technologies; Chamy, R., Rosenkranz, F., Soler, L., Eds.; In Tech: Rijeka, Croatia, 2015.

30. Kaushik, P.; Malik, A. Fungal dye decolourisation, recent advances and future potential. Environ. Int. 2009, 35, 127-141. [CrossRef] [PubMed]

31. Palli, L.; Gullotto, A.; Tilli, S.; Gori, R.; Lubello, C.; Scozzafava, A. Effect of carbon source on the degradation of 2-naphthalenesulfonic acid polymers mixture by Pleurotus ostreatus in petrochemical wastewater. Process. Biochem. 2014, 49, 2272-2278. [CrossRef]

32. Tilli, S.; Mori, G.; Mannucci, A.; Munz, G.; Gori, R.; Lubello, C.; Scozzafava, A.; Varese, G.C.; Briganti, F. Natural Tannins for Leather Treatments: Biodegradation by Penicillium Chrysogenum Mut 4444 on a Fixed Bed Bioreactor. In Proceedings of the "Oxidative Enzymes as Sustainable Industrial Catalysts", Santiago de Compostela, Spain, 14-15 September 2010; pp. 270-275.

33. Anastasi, A.; Parato, B.; Spina, F.; Tigini, V.; Prigione, V.; Varese, G.C. Decolourisation and detoxification in the fungal treatment of textile wastewaters from dyeing processes. New Biotechnol. 2011, 29, 38-45. [CrossRef] [PubMed]

34. Steffen, K.T.; Hatakka, A.; Hofrichter, M. Degradation of humic acids by the litter-decomposing basidiomycete Collybia dryophila. Appl. Environ. Microbiol. 2002, 68, 3442-3448. [CrossRef] [PubMed]

35. Murugan, K.; Saravanababu, S.; Arunachalam, M. Screening of tannin acyl hydrolase (EC 3.1. 1.20) producing tannery effluent fungal isolates using simple agar plate and SmF process. Bioresour. Technol. 2007, 98, 946-949. [CrossRef] [PubMed]

(C) 2017 by the authors. Licensee MDPI, Basel, Switzerland. This article is an open access article distributed under the terms and conditions of the Creative Commons Attribution (CC BY) license (http:/ / creativecommons.org/licenses/by/4.0/). 